Canadian University Music Review

Revue de musique des universités canadiennes

\title{
New Issues in the Analysis of Webern's 12-tone Music
}

\section{Catherine Nolan}

Volume 9, numéro 1, 1988

URI : https://id.erudit.org/iderudit/1014924ar

DOI : https://doi.org/10.7202/1014924ar

Aller au sommaire du numéro

Éditeur(s)

Canadian University Music Society / Société de musique des universités

canadiennes

ISSN

0710-0353 (imprimé)

2291-2436 (numérique)

Découvrir la revue

Citer cet article

Nolan, C. (1988). New Issues in the Analysis of Webern's 12-tone Music. Canadian University Music Review / Revue de musique des universités

canadiennes, 9(1), 83-103. https://doi.org/10.7202/1014924ar

All Rights Reserved (C Canadian University Music Society / Société de musique des universités canadiennes, 1988
Ce document est protégé par la loi sur le droit d'auteur. L'utilisation des services d’Érudit (y compris la reproduction) est assujettie à sa politique d'utilisation que vous pouvez consulter en ligne.

https://apropos.erudit.org/fr/usagers/politique-dutilisation/ 


\section{NEW ISSUES IN THE ANALYSIS OF WEBERN'S 12-TONE MUSIC 1}

\section{Catherine Nolan*}

The awakening of interest in Webern's music in the years following World War II coincided with a resurgence of intellectual concern about the twelve-tone method, already over twenty years old. Milton Babbitt, the principal pioneer of this development, revealed in his seminal articles of the 1950s and '60s the structural properties of the 48 transformations of a twelve-tone row. As Babbitt pointed out, the focus of this invigorated interest in the twelve-tone method took two forms that of total serialism (or total organization) in Europe, and that of increasingly rigorous exploration and modelling of the twelve-tone system as a mathematical group in the United States (Babbitt 1955). On both sides of the Atlantic, Webern was frequently chosen as the composer most representative of each of these respective positions. In Europe, early advocates of total serialism, including Messiaen, Boulez, Dallapiccola and Stockhausen, were inspired by Webern because of some regular recurrences in his use of rhythm and articulation in applying the twelve-tone method, which, to them, suggested serial extension into non-pitch domains. In America, Babbitt cited the rows of Webern's Concerto for Nine Instruments Op.24 and the Piano Variations $\mathrm{Op.27}$ in his discussions of certain general mathematical properties of inversionally related rows and rows derived from smaller source sets, in the article cited above and his well-known article

1 I wish to express my appreciation to Allen Forte for his characteristically sensitive and thorough reading of this paper in an earlier version.

* Catherine Nolan is the first winner of the George Proctor Prize awarded for the best paper presented by a graduate student at the annual meeting of the Canadian University Music Society. [Editor's note] 
"Twelve-Tone Invariants as Compositional Determinants" (Babbitt 1960).

Although the two positions represent quite different manifestations of Webern's influence, they share as a common point of departure the reflection of the personal compositional, as distinct from analytical, concerns of their proponents. Now, with the benefit of hindsight, we can see that they demonstrate a certain lack of analytical objectivity toward this distinctive repertoire. Both are products of compositional, not analytical, theory.

This paper begins with a brief critique of some of the more important writings that have stimulated the production of a large body of literature about Webern's music and research into the general properties of the twelve-tone system. In much of this literature, the underlying assumptions echo the compositional inclinations of the early writers, and the analyses rarely transcend the level of row construction and succession. Through a discussion of questions which arise through segmentation in selected short passages from the instrumental twelvetone works, this paper will lay the framework for a new analytical approach to Webern's instrumental twelve-tone music using a hierarchic model. ${ }^{2}$

The ultimate goal of the paper is to demonstrate that structural unity in Webern's twelve-tone music is obtained not merely by the presence of serial control of pitch-classes, but more immediately by pitch or pitch-class associations created by contextual features.

Webern's Concerto for Nine Instruments Op.24 has been regarded as an important example for analysis from both points of view outlined above, that is, the view of Webern as an incipient total serialist, and the view of Webern's row structures as models of the properties of the twelve-tone system. Stockhausen, in his analysis of the first movement,

2 I am omitting the vocal works from my study, partly because of the need for objectively defined limits, but primarily because of the complex interaction of musical and poetic forms, and the limitations imposed on the use of register by the voice. 
discusses the permutations of the pitch-classes of the trichords in subsequent row statements, and attempts to relate these permutations to isolated occurrences of permuted series of durational values and modes of articulation (Stockhausen 1953). The intention of Stockhausen's essay is clearly to bring a historical precedent to the new ideal of total serialism, not to deepen our understanding of Webern's music in its own right.

Babbitt discusses the properties of the row for Op. 24, particularly as an example of a derived row (Babbitt 1955). Figure 1 shows the row of Op.24 in letter and pitch-class numeric notation and its derivation from the initial 3-3 trichord, using the four basic operations of the twelve-tone system: prime (P), inversion (I), retrograde-prime (RP), and retrograde-inversion (RI). ${ }^{3}$ Babbitt and George Perle (Perle 1981: 79-80) both comment on the structural implications of trichordal combinatoriality built into this row, and imply tacitly that Webern was perhaps remiss in not exploiting this property compositionally to construct aggregates as Schoenberg did in his combinatorial works. As Figure 2 shows, the initial row statement, P11, is trichordally combinatorial with three other row forms, RP5, I0 and RI6. Figure 2 also illustrates the relationships among the four primary trichords in each row form, using the letters $a$ through $d$ to identify the recurrent pitchclasses of the trichords. The entire matrix of $\mathbf{4 8}$ row forms divides itself into twelve isomorphic subgroups of four row forms related by trichordal combinatoriality.

Babbitt, in his writings, focuses virtually exclusively on the row as a structure unto itself, with its own intrinsic properties and internal relations, and separate from Webern's composition. As enormously important as Babbitt's contributions to twelve-tone theory are, he left open many crucial questions about harmonic structure in Webern's music, which is not surprising since his concern lay more with exposing the general properties of the twelve-tone system than with Webern's specific applications.

3 The nomenclature and terminology for pitch-class sets is from Forte, (1973). 


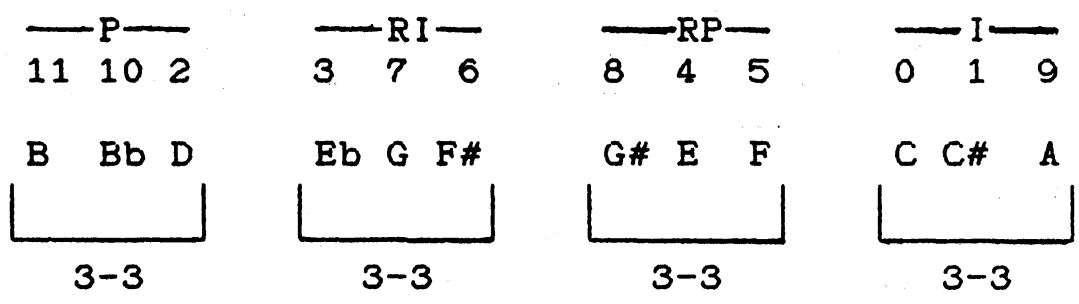

Figure 1. : Row for Op. 24 and trichordal derivation

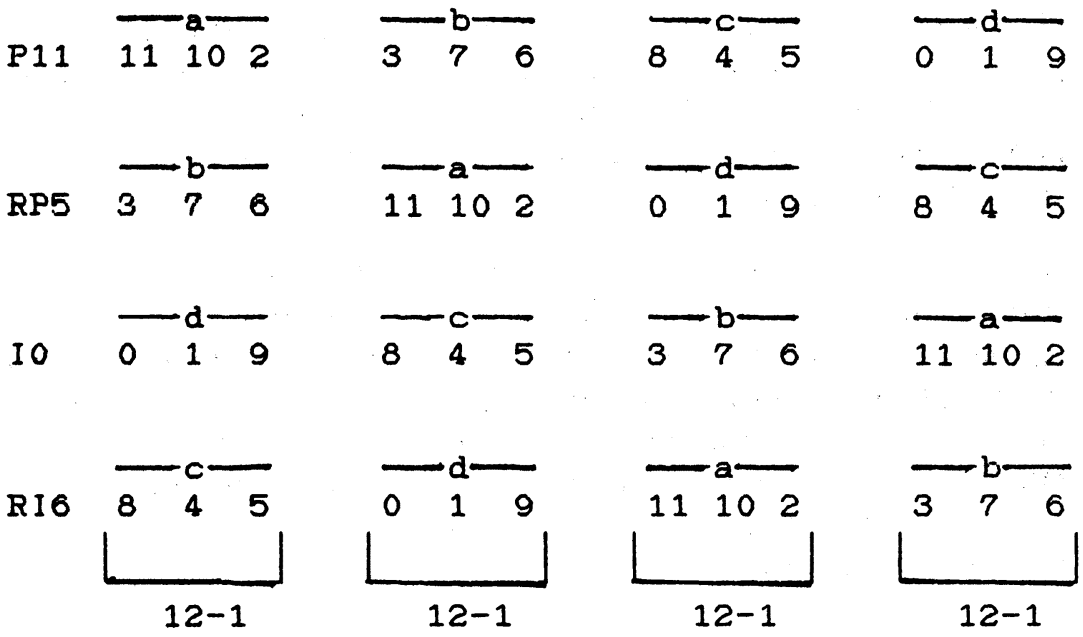

Figure 2. : Trichordally related row forms, Op. 24 
a. Construction of the principal hexachord

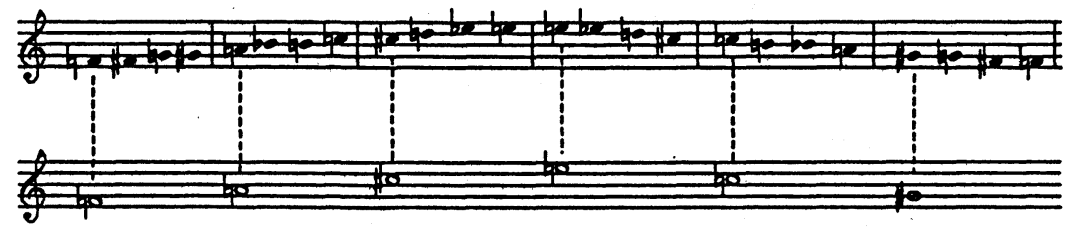

b. First reordering of the principal hexachord

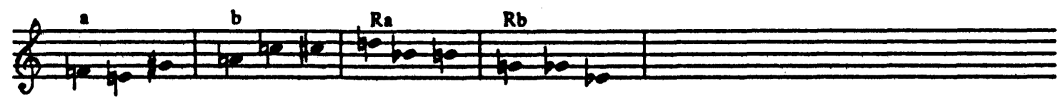

c. Final reordering of the principal hexachord

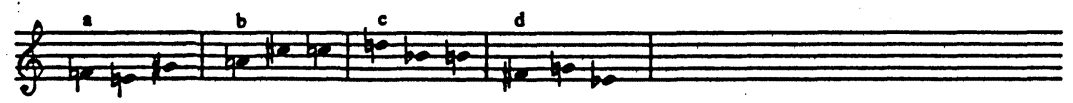

d. Permutational relationships between trichordal pairs

\begin{tabular}{|c|c|c|c|}
\hline $\mathbf{a}$ & b & c & d \\
\hline$P$ & $\mathrm{RI}$ & $R P$ & I \\
\hline RI & $\mathbf{P}$ & I & $\mathrm{RP}$ \\
\hline $\mathrm{RP}$ & I & $\mathbf{P}$ & R I \\
\hline I & $R P$ & RI & $P$ \\
\hline
\end{tabular}

Figure 3. : Webern's Stages for Determining the Row for Op. 24 
To illustrate this, I will discuss Webern's sketches for Op.24, which reveal that he determined the content of the primary hexachord of the row first, before reordering the pitch-classes into their final trichordal form. In Figure 3, I show the stages in Webern's working out of the basic row for Op.24.4 Figure 3a shows how he wrote out the complete chromatic scale ascending and descending from $\mathrm{f}^{1}$ (using Schenker's register designations), partitioned it into tetrachords, and extracted the first note of each tetrachord to form two augmented triads separated by a semitone, a representation of hexachord 6-20. Figure $3 \mathrm{~b}$ shows Webern's first reordering of the 6-20 hexachord as two 3-3 trichords which are unrelated by ordered transposition, inversion or their retrogrades. The second hexachord of the row at this stage is ordered as transposed retrogrades of the first two trichords. Figure $3 \mathrm{c}$ shows Webern's final reordering of the 6-20 hexachord, in which the second trichord is reordered to become the retrograde-inversion of the first, and each trichord can be derived from any other by one of the four twelve-tone operations. ${ }^{5}$ The relationships between all pairs of trichords are shown in the group table of Figure 3d.

Close study of the first movement of Op.24 suggests that Webern was primarily concerned with exploring the limited harmonic resources of the 6-20 hexachord, which is the set-class name for Babbitt's third-order all-combinatorial source set. This means, in effect, that half of the row forms in the row matrix contain identical hexachords by unordered pitch-class content. The trichordally combinatorial subgroups represent cases of segmental invariance among the larger family of 24 row forms with identical hexachordal content. The intricate trichordal interrelationships, then, which although probably the feature most discussed in references to Op.24, are not necessarily the most significant feature of

4 The stages in Webern's working out of the ordering of the row for Op.24 are deduced from the Moldenhauer edition of facsimile reproductions of pages from Webern's sketchbooks (Moldenhauer, comp. 1965: Plates 33 and 34). The interested reader may also wish to consult Smalley (1975: 5-8). The sketchbooks themselves are now housed at the Paul Sacher Stiftung in Basel, Switzerland.

5 In the composition itself, Webern chose to transpose the row by a tritone. 
the work. The discussions of the derivation of the row for Op.24 by Babbitt and Perle and others illustrate the tendency of authors to place more emphasis on the construction of the row than on specific details of harmonic structure of the music itself. 6

The underlying assumption in Babbitt's and Perle's writings on twelvetone music during the '50s and '60s, and which with few exceptions persists through more recent writings, is that the internal structure of the row and the relationships among the transpositions, inversions and retrogrades of the row employed in the composition determine the structure of the musical work. Without intending to denigrate the significance of these aspects as starting points in any analysis of a twelve-tone work, I must point out that this stage is actually preanalytical, in that little broad interpretation of the music is involved.

Since Babbitt's groundbreaking theoretical articles and Perle's empirical study of row techniques used by the Second Viennese School, many studies of the twelve-tone method have been devoted to further extensions beyond the "classical" method set forth by Schoenberg. These extensions involve expanding the basic operations to include the multiplicative operations applied to the pitch-classes of the row, and circular permutation (also known as rotation) applied to the order positions of the row. Robert Morris and Daniel Starr have also contributed exhaustive generalized studies of combinatoriality and on the structure of all-interval series (Starr and Morris 1977/78; Morris and Starr 1974). These studies and developments, though impressive in disclosing the seemingly endless resources of the twelve-tone system, do not add significantly to our analytical techniques in dealing directly with the "classical" twelve-tone music of Schoenberg, Berg and Webern. Here again, compositional theory obscures the real problem, that of understanding Webern's music in its own terms.

Webern's twelve-tone music presents the analyst with unique issues, distinct from Schoenberg or Berg, because of his surface fragmentation

6 Other examples of this tendency include Eimert (1961), Pousseur (1966), Spinner (1955) and Whittall (1970). 
of the row into its small segments on the one hand, and because of his frequent harmonic texture of two or more simultaneously unfolding row forms, often in canon, on the other hand. Simultaneities in these circumstances are rarely verticalizations of linear row segments, nor are they equivalent with any degree of consistency to linear row segments, as Martha Hyde has shown to be the case with Schoenberg (Hyde 1982).

The absence of a serious investigation into Webern's twelve-tone harmony and its relation to form among the profusion of publications on his music, is a serious lacuna in contemporary theoretical research. Most of the existing literature on Webern's twelve-tone music is confined to compositional issues dealing with row successions and foreground motivic/rhythmic features, and moreover, are usually restricted to a single piece or movement.

Arnold Whittall's insightful portrayal of the state of Webern research in 1970 still rings true today, with only a few notable exceptions. ${ }^{7}$

What was once incomprehensible [about Webern's twelve-tone music], and therefore boring, is now, for many students oriented by Stockhausen and Babbitt, predictable - and boring. Certainly analysis of Webern might seem unnecessary when the surface of his music is so clear in its motivic evolutions, contrapuntal relationships and timbral distributions. The successive stages and overall unity of his music become increasingly apparent to the experienced ear, and the succession of twelve-tone sets is identifiable with a little effort

(Whittall 1970: 54 [italics mine]).

Christopher Hasty has addressed this problem by developing a theory of segmentation for post-tonal music which does not distinguish between different compositional methods (Hasty 1981). His examples are drawn from atonal, pre-serial and twelve-tone works, each with its

7 These exceptional analytic treatments of twelve-tone works by Webern include Wintle (1982) and Hasty (1981: 63-69) on Op.24/II, and Westergaard (1966) on Op.27/II. 
unique analytical challenges. Hasty attempts to find a meeting point between sensitive and introspective listening and the development of systematic criteria for segmentation on the basis of one's informed perceptions. This phenomenological approach succeeds in conveying the complexity of the problems involved in analyzing harmonic structure in post-tonal music. In a more recent article Hasty continues to refine his approach to contextual analysis as well as the specific problems posed by Webern's twelve-tone music, and stresses the point that the row should not be uncritically assumed to be the sole structural determinant in a twelve-tone work (Hasty 1988).

Even a conventional set-theoretic analysis suggests that Webern consciously separated the structure of the row from the textural surface of the music. In Figure 4a, I show the opening gesture of Op.24/I, encompassing the first statement of the row. Although each trichord of the derived row is differentiated by means of instrumentation, duration, intervallic succession and articulation, one can hear other relationships as equally or more informative of the harmonic structure. The fact that the trichords overlap each other by one note brings out other, less obvious symmetries, as shown in Figure $4 \mathrm{~b}$. Here the segmentation divides the row into a pentad and a heptad, reflecting the change from duple to triple durational values. All the pitches up to and including the simultaneous attacks at the duple/triple division point form set 7-21, while those up to, but not including these attacks form its complement 5-21.

A similar example is shown in Figure 5a, the opening row statement of the first movement of the String Quartet Op.28. The row for Op.28, shown in Figure $5 \mathrm{~b}$, has special combinatorial properties because of its derivation from the chromatic 4-1 tetrachord (the B-A-C-H motive), but as in Op.24, these properties are not exploited in the piece. The opening gesture encompasses a complete statement of the row in which the tetrachordal symmetry is virtually imperceptible in terms of register, articulation and melodic contour. That is to say, the distribution of the pitches does not congenially allow for an analytical segmentation that 
a)

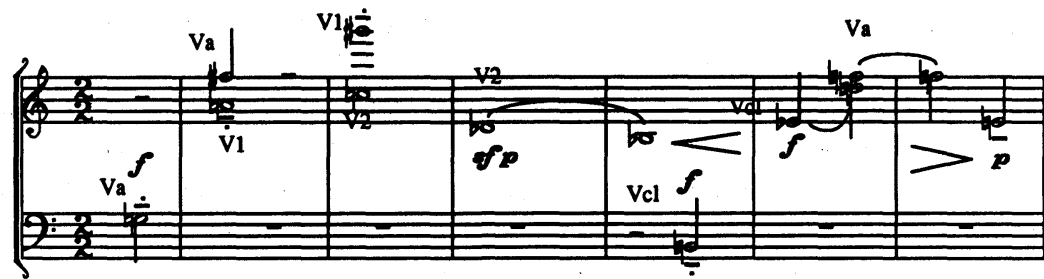

$\begin{array}{llll}7 & 6 & 9 & 8\end{array}$

b)
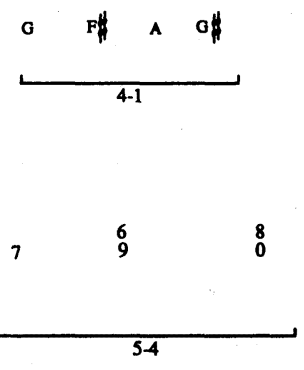

c)
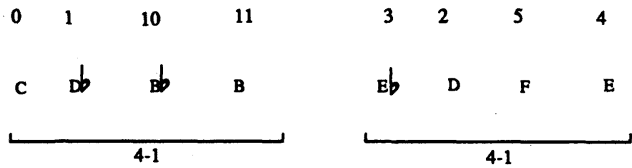

\begin{tabular}{lll}
7 & 9 & 8 \\
& & 0 \\
\hline
\end{tabular}

$7-4$

$7-4$

Webern Concerto for Nine Instruments, Opus 24 Copyright 1948 by Universal Edition A.G. Wien

Copyright Renewed

All Rights Reserved

Used by permission of European American Music

Distributors Corporation, sole U.S. and Canadian agent

for Universal Edition Vienna

Figure 4. : Concerto for 9 Instruments, Op. 24/I, mm.1-3

partitions the row statement into its discrete tetrachords. The arrangement of single pitches, simultaneities and slurred dyads suggests a partitioning of the passage into $5+2+5$, thereby concealing the tetrachordal symmetry $(4+4+4)$ of the basic row. This results in the primary segmentation into complementary set-classes $5-4 / 7-4$, as shown 
in Figure 5b. The outer 5-4 segments are associated by their identical duration of five half notes, and the union of either pentad with the distinctive minor-third dyad that separates them results in the complement of the pentad. It is significant that with all the symmetries available among the equal partitions of this particular row, Webern chose to suppress them in favour of a less obvious partitioning.

a)

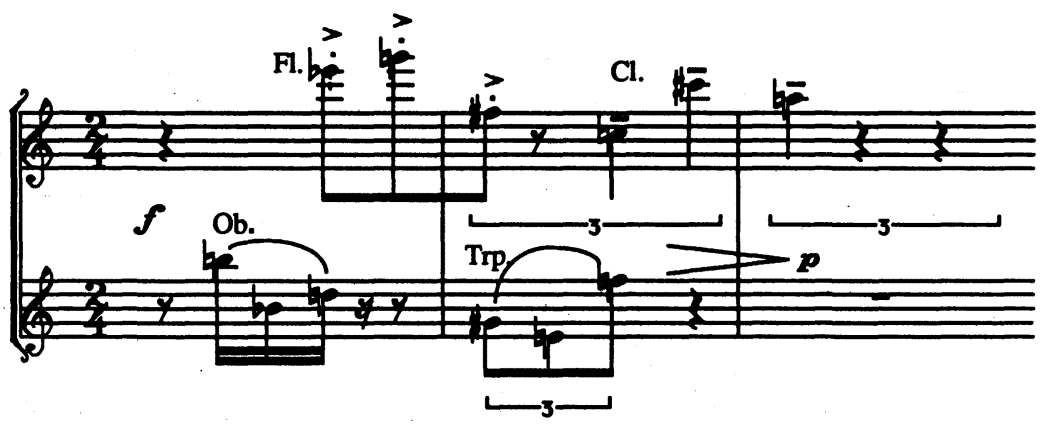

b)
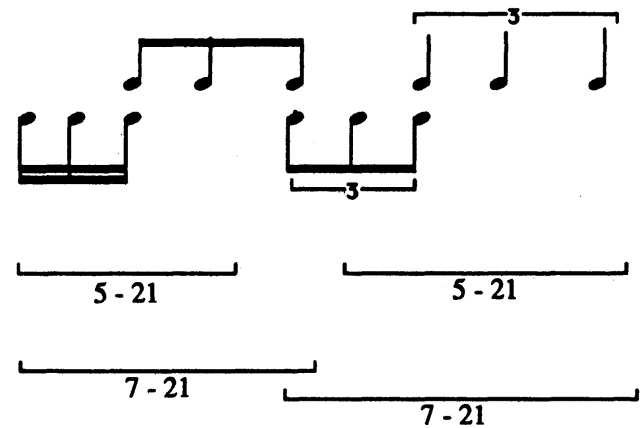

Webern String Quartet, Opus 28

Copyright 1939 by Hawkes and Sons (London) Ltd.

Copyright Assigned 1955 to Universal Edition A.G. Wien

Copyright Renewed

All Rights Reserved

Used by permission of European American Music

Distributors Corporation, sole U.S. and Canadian agent

for Universal Edition Vienna

Figure 5. : $\quad$ String Quartet Op. 28/I, mm.1-6 
The previous two examples illustrate well how the transference of the linear ordering of the pitch-classes of the row to the particular compositional context can bring about new relationships, more complex than those embodied by precompositional derivation from a source trichord or tetrachord, or other types of symmetries. We will now proceed to another example in order to study longer-range harmonic structure.

a)

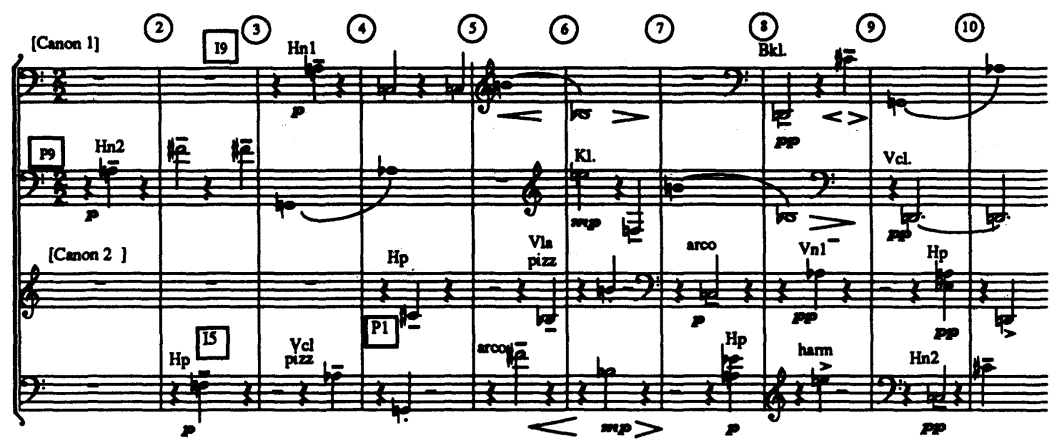

b)

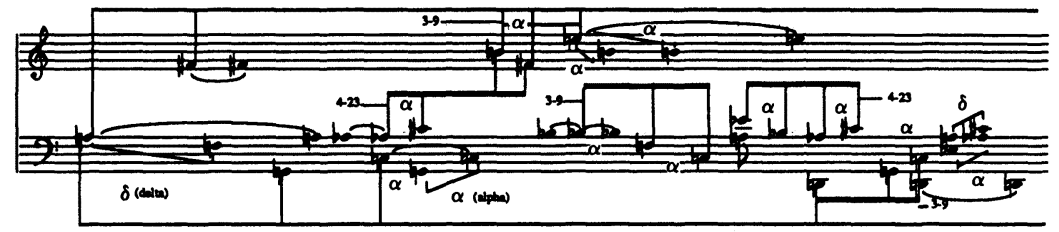

Webern Symphonie, Opus 21

Copyright 1929 by Universal Edition

Copyright Renewed

All Rights Reserved

Used by permission of European American Music

Distributors Corporation, sole U.S. and Canadian agent

for Universal Edition Vienna

Figure 6. : Symphony Op. 21/I, mm.1-10 
The opening ten measures of the first movement of the Symphony Op.21 are particularly illuminating. A short score is provided in Figure $6 \mathrm{a},{ }^{8}$ and Figure $6 \mathrm{~b}$ shows my graphic analysis. The predominant motivic component in this passage is the interval of the perfect fourth, which I refer to here as motive alpha $(\alpha)$. Motive alpha generates the two most prominent foreground set-classes, as well as the larger middleground discussed below. Figure 7 shows that a concatenation of two perfect fourths results in set-class 3-9; of three perfect fourths, set-class 4-23; and of six perfect fourths, 7-35.9

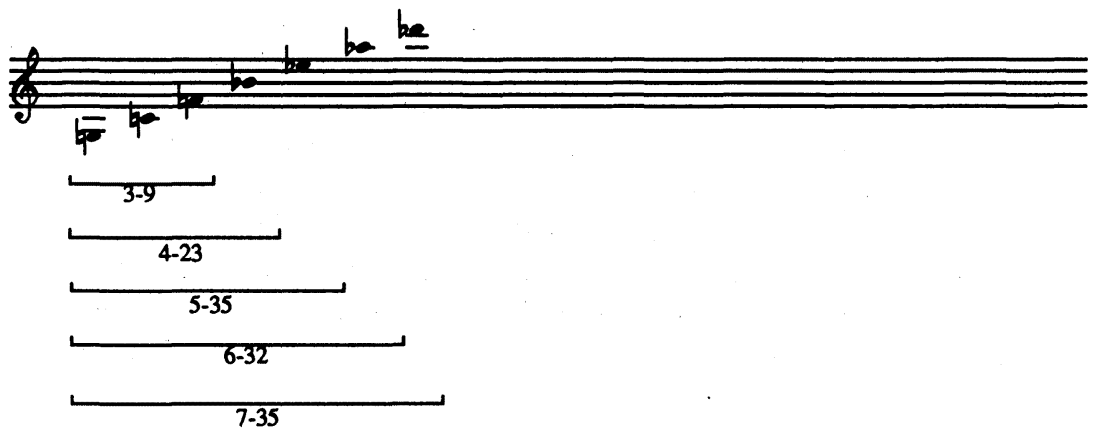

Figure 7. : Set-classes of successive concatenations of perfect fourths

8 The short score is arranged according to the double canon which underlies the movement. Pitches within each staff are adjacencies within the row-form indicated at its beginning.

9 A complete theoretical explanation of the processes upon which these formulations and the analysis which follows are based is beyond the scope of the present article. The amount of detail provided, however, should be consistent with the stated aims of the paper. 
As just mentioned, set-classes 3-9 and 4-23 dominate the foreground of the passage in question, and most significantly, their occurrences are in almost all cases products of non-adjacent pitches of a single row form, or of different row forms. The only other motivic interval indicated in this analysis is motive delta $(\delta)$, the major third, from $a$ to $f$ at the beginning, and $a$ to $c^{1}$ at the end of this passage, and its chief significance is to frame the passage as a unit. It is important to bear in mind that these motivic intervals are deduced from the musical foreground, not induced by the operations of the twelve-tone system.

The set-classes generated from the alpha motive, 3-9 and 4-23, also control the middleground of the passage, as indicated by the highestand lowest-level beams in the analysis. The pitches that form the middleground $-a, f^{1} b^{1}$ and $e^{2}$ in the upper range, and $a, c, G$ and $D$ in the lower range (see Figure 8) - are associated by some shared structural characteristics. Each pitch enters for the first time on a metric downbeat, with the exception of the initiating $a$. This separates the $a$ from the remaining texture, bringing out the unfolded 3-9 trichords in each register; it also assists in our perception of $a$ as the axis of registral symmetry of the entire exposition. Each component of the middleground is also introduced by the same instrument, the horn, until the registral extrema are reached; the high $e^{2}$ and the low $D$ are introduced by the clarinet and bass clarinet respectively.

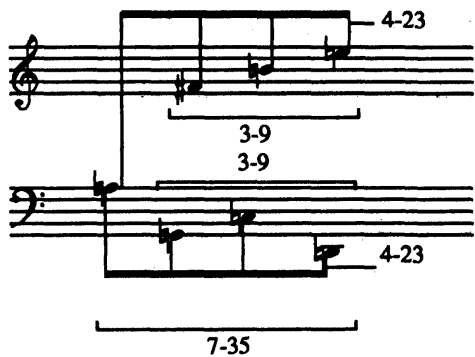

Figure 8. : Middleground structure of Op. 21/I, mm. 1-10 
The middleground structure of this passage apparently bears little relation to the row of the piece. Its total pitch-class content, set-class 7-35, is not equivalent to any linear segment of the row, and neither are its prominent subsets 3-9 or $4-23$, all members of the collection of setclasses generated by motive alpha, the perfect fourth. The structural levels are articulated through motivic congruence between foreground and middleground, and not through consistency within the twelve-tone system. This example was selected because of the simplicity of its texture and intervallic components. The final analytic example, from the beginning of the development of the same movement, Op.21/I, will serve as an introductory illustration of a more complex texture whose underlying motivic structure is internally consistent at the foreground and middleground levels, as well as consistent with motivic materials set forth at the opening of the work. This passage is reproduced in short score in Figure 9a, with its analysis in $9 b$.

The new motivic interval, gamma ( $\gamma$ ), the minor third, enters conspicuously on $e^{2}$ twice in the clarinet, at $\mathrm{m} .25 \mathrm{~b}$ and $\mathrm{m} .28$. The first occurence, $e^{2}-g,{ }^{2}$ is between row adjacencies, but the second, $e^{2}$. $c^{2}$, is not, again showing the priority of registral intervals over the linear ordering of the row. Motive delta recurs over a longer span between $f^{3}$ and $d^{3}$ (mm.27-29), between low $G$ and $E$ (mm.30-32), and allowing for certain significant octave transfers, between $e^{2}$ and $g^{4}$ (mm.25b-33), and between low $c$ and $A$ (mm. 26-33), thus taking in and unifying the entire phrase. This ostensibly new motive delta is related to the opening pitches of the movement, $a-f^{1}$, by shared interval class, demonstrating that the basic row is not to be rejected wholesale as a source for motivic material in the sense I have defined, but must be considered alongside the primary contextual features of temporal order, register, instrumentation, timbre, duration, and so forth. As if to confirm the connection between motive delta and the opening horn notes, its last occurrence in the passage (m.33), takes place in the clarinet, the instrument with which it entered, using the original pitchclasses. 

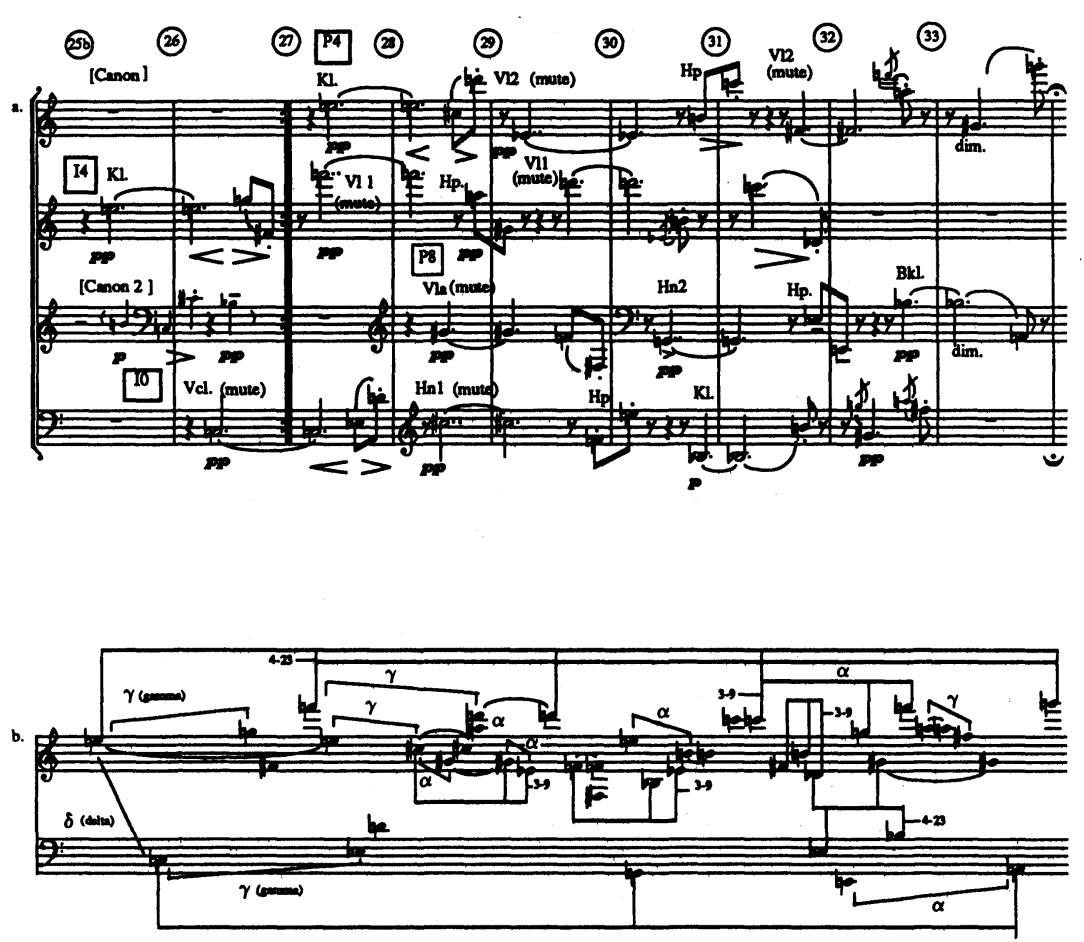

Webern Symphonie, Opus 21

Copyright 1929 by Universal Edition

Copyright Renewed

All Rights Reserved

Used by permission of European American Music

Distributors Corporation, sole U.S. and Canadian agent for Universal Edition Vienna

Figure 9. : Symphony Op. 21/I, mm. 25b-33

Recurrences of motive alpha and its associated set-classes are indicated in the example. The middleground, here determined primarily on the basis of register and shown again by the highest- and lowest-level beams, comprises set-class 6-32, which belongs to the collection of setclasses formed by concatenations of perfect fourths. (See Figure 7.) 
The analytical approach introduced here is obviously influenced by Schenker's theory of structural levels, although, needless to say, there is no possibility of a tonal interpretation of the music. There are also important philosophical divergences from Schenker, such as the absence of linear motion or voice-leading. The issue of structural levels in post-tonal music has become an important area of theoretical investigation. Allen Forte, for instance, demonstrates that, while tonal interpretations may be found for certain passages in Berg's Wozzeck, a more penetrating view of harmonic structure comes from examining the recurrences of prominent foreground motives at deeper levels of structure (Forte 1985). In Berg's music in general, and in Wozzeck in particular, the identity of significant motives is relatively clear. But because of the fragmentary character of individual instrumental lines in Webern's twelve-tone music, in contrast to Berg's, motivic units are often ambiguous, and to identify them becomes part of the analytical challenge.

In addition to introducing a new analytical approach to Webern's music, I have tried to briefly address some critical theoretical issues, for example, the question of hierarchic structure within a permutational system. There is no doubt that Webern usually constructed his rows to bring out a symmetric organization which reduces the total number of discrete row forms. Symmetries, which by definition are undifferentiated, are juxtaposed with hierarchies on the musical surface. A conflict arises here between the "precomposition", that is, the abstraction of the row, and the composition itself. By confronting this dialectical problem, perhaps some light may be shed on the intense lyricism of Webern's twelve-tone music, a quality which I believe many listeners appreciate, but which the theoretical and analytical literature has, for the most part, ignored.

Another interesting theoretical question is Webern's selective use of only a few hexachords as primary row segments in his entire twelve-tone oeuvre. With the exception of Op.24, whose row is based on the 6-20 hexachord as noted above, all of Webern's rows in the published instrumental works from Op.20 on use only three hexachords: 6-1, 6-2 and 6-5. Although within a single work the unordered hexachordal content of the row does not seem to have played a central role (with the 
notable exception of $\mathrm{Op.24}$, as discussed earlier), in the larger context of this repertoire the composer may have been interested in different foreground orderings of a limited number of closely related unordered collections. Figure 10 shows the rows of these works and their constit-

$\begin{array}{rrrrrrrrrrrrrr}\text { 6-1 Op. } 21 & 9 & 6 & 7 & 8 & 4 & 5 & 11 & 10 & 2 & 1 & 0 & 3 \\ & \text { Op. } 27 & 4 & 5 & 1 & 3 & 0 & 2 & 8 & 9 & 10 & 6 & 7 & 11 \\ & \text { Op. } 30 & 9 & 10 & 1 & 0 & 11 & 2 & 3 & 6 & 5 & 4 & 7 & 8\end{array}$

[also Op. 17/3, Op. $18 / 2$ and projected Op. 32]

$\begin{array}{lllllllllllllll}6-2 & \text { Op. } 22 & 1 & 10 & 9 & 0 & 11 & 3 & 4 & 5 & 6 & 8 & 2 & 7\end{array}$ [also Op.25 and Op.29]

$\begin{array}{rlllllllllllll}6-5 & \text { Op. } 20 & 3 & 4 & 8 & 7 & 2 & 1 & 9 & 10 & 5 & 6 & 11 & 0 \\ & \text { Op. } 28 & 7 & 6 & 9 & 8 & 0 & 1 & 10 & 11 & 3 & 2 & 5 & 4\end{array}$
[a]so Op. 17/2]

$\begin{array}{llllllllllllll}6-20 & \text { Op. } 24 & 11 & 10 & 2 & 3 & 7 & 6 & 8 & 4 & 5 & 0 & 1 & 9\end{array}$

Figure 10. : Rows for instrumental works from Op. 20 to Op. 30 arranged by principal hexachord. 
uent primary hexachords. Other twelve-tone works by Webern that fall outside the purely instrumental works under consideration, but whose rows nevertheless exhibit the same principal hexachords are shown in brackets in Figure 10, further demonstrating the pervasiveness of these few set-classes as primary row segments.

In this paper I have attempted to convey the need for an in-depth study of Webern's harmonic structure in his twelve-tone works. Twelve-tone theory since the 1950s, at least where Webern's music is concerned, has tended to emphasize compositional, not analytical, applications - to look forward, rather than backward to the earliest practitioners of the method. This is not a bad thing in itself; in fact, it has contributed greatly to the techniques and inspiration of numerous major composers, but it bypasses or at least diminishes factors outside the row construction which endow Webern's twelve-tone music with its overall harmonic structure. There is no question that Webern's music is artistically rich enough to merit this sort of concentrated study of its own accord, not only as an inspirational source for other composers, and that now is an opportune time to pursue such a study. With the growth of the field of music theory we have well-developed analytical tools to draw upon, and we now have greater historical objectivity about the twelve-tone method, an objectivity that enables us to distinguish easily between theoretical constructs intended to aid the composer and theoretical constructs intended to illuminate the music from an analytical standpoint.

Webern's later music represents an exquisite synthesis of craft and art. The brevity of the movements and the uncomplicated appearance of the scores belie great complexities of surface detail and of harmonic design. I am convinced that it is these complexities of design, and not merely the abstraction of row construction and successions, which prove most captivating to the ears of musicians and listeners. 


\section{REFERENCES}

BABBITT, MILTON.

1955: "Some Aspects of Twelve-Tone Composition," The Score and I.M.A. Magazine, 12: 53-61.

1960: "Twelve-Tone Invariants as Compositional Determinants," Musical Quarterly, 46: 246-259.

1961: "Set Structure as a Compositional Determinant," Journal of Music Theory, 5/1: 72-94.

EIMERT, HERBERT.

1961: "Die elektronische Musik," Österreichische Musikzeitschrift, 16: 316-320.

FORTE, ALLEN.

1973: The Structure of Atonal Music. New Haven: Yale University Press.

1985: "Tonality, Symbol and Structural Levels in Berg's Wozzeck," Musical Quarterly, 71: 474-499.

\section{HASTY, CHRISTOPHER.}

1981: "Segmentation and Process in Post-Tonal Music," Music Theory Spectrum, 3: 54-73.

1988: "Composition and Context in Twelve-Note Music of Anton Webern," Music Analysis, 7/3 (forthcoming).

HYDE, MARTHA.

1982: Schoenberg's Twelve-Tone Harmony: The Suite Op.29 and the Compositional Sketches. Ann Arbor, Michigan: UMI Research Press.

MOLDENHAUER, HANS, compiler.

1965: Anton von Webern: Sketches (1926-1945). Facsimile reproduction from the composer's sketchbooks in the Moldenhauer Archive. [Now at the Paul Sacher Stiftung, Basel, Switzerland] Commentary by Ernst Krenek with a Foreword by Hans Moldenhauer. New York: Carl Fischer, Inc.

MORRIS, ROBERT and DANIEL STARR.

1974: "The Structure of All-Interval Series," Journal of Music Theory, 18/2: 364-389.

PERLE, GEORGE.

1981: Serial Composition and Atonality. Fifth edition. Berkeley, Los Angeles and London: University of California Press.

POUSSEUR, HENRI.

1966: "The Question of Order in New Music," Perspectives of New Music, 5/1: 93-111. 
SMALLEY, ROGER.

1975: "Webern's Sketches (I)," Tempo, 112: 2-12.

SPINNER, LEOPOLD.

1955: "Analyse einer Periode - Konzert für 9 Instrumente, op.24, 2.Satz," Die Reihe, 2: 51-55.

STARR, DANIEL and ROBERT MORRIS.

1977/78: "A General Theory of Combinatoriality and the Aggregate," Perspectives of New Music, 16/1, 3-35; Perspectives of New Music, 16/2: 50-84.

STOCKHAUSEN, KARLHEINZ.

1953: "Weberns Konzert für 9 Instrumente op.24 - Analyse des ersten Satzes," Melos, 12: 343-348.

WESTERGAARD, PETER.

1966: “Webern and 'Total Organization': An Analysis of the Second Movement of the Piano Variations, Op.27," Perspectives of New Music, 4, 90-112.

WHITTALL, ARNOLD.

1970: "On Summarizing Webern," Soundings, 1: 54-57.

WINTLE, CHRISTOPHER.

1982: "Analysis and Performance: Webern's Concerto Op.24/II," Music Analysis, 1/1: 73-99. 